\title{
Effectiveness of Information Education Communication Package on knowledge regarding Dysmenorrhea Among Adolescent Girls in selected schools at Puducherry
}

${ }^{*}$ Ms.sharisadan, ${ }^{* *}$ Prof.M.AnnieAnnal.M\& ${ }^{* * *}$ Mrs.Poongodi.V

\begin{abstract}
:
Objectives: To assess the level of knowledge on management of dysmenorrhea among adolescent girls during pre-test, to assess the effectiveness of information education communication package on knowledge regarding management of dysmenorrhea among adolescent girls during post-test, to find the association between the knowledge on management of dysmenorrhea and selected demographic variables. Methods: quasi experimental research design was adopted for the study. Result: the study findings revealed that 42(70\%) of the adolescent girls had inadequate knowledge, 18(30\%) had moderately adequate knowledge and none of the adolescent girls had adequate knowledge during pre-test. In the post- test, greater strength of the adolescent girls 37(61\%) had adequate knowledge, 23(39\%) had moderately adequate knowledge and none of the adolescent girls had inadequate knowledge. Conclusion: from this study it was clearly proved that proper information education communication package on management of dysmenorrheal will surely improve the knowledge level of the adolescent girls.
\end{abstract}

Key words : Assess, Information Education Communication (IEC) Package, Management of Dysmenorrhea, Knowledge, Adolescentgirls

\section{INTRODUCTION}

Menstruation is the monthly cycle; it is experienced by women from puberty to menopause. Most of the women experience menstruation once in 28 days, but it can vary considerably from one person to another. Though the menstruation is normal, some women experience dilemma during their monthly periods. The commonly experienced problem by the women is cramping pain during menstruation, known as Dysmenorrhea. It is the common cause of sickness absenteeism (30 to 51\%) from classes and work by the female student community.

\section{NEED FOR THE STUDY}

Various studies in India revealed that the prevalence of dysmenorrhea varies from 33\% to $79.67 \%$. According to studies dysmenorrheal interrupt the educational as well as social life. Due to dysmenorrheal sickness absenteeism and perceived quality of life losses are prevalent among adolescent girls, that is about $28-56 \%$. The pain during menstruation affects $40 \%$ to $95 \%$ of menstruating women and has been reported as the most common cause of regular absenteeism among adolescents.

Menstruation is considered as a normal phenomenon, it is considered as highly emotional experience for adolescent girls. 
Many studies revealed that Dysmenorrhea is associated with several physical and psychological problems, which are merely to be complicated by a confusion caused by incomplete and wrong information among adolescents about the menstrual problems and treatment. Majority of the adolescent girls especially in rural areas are not aware of how to manage Dysmenorrhea. So by providing IEC (Information, Education, Communication) Package to impart knowledge on management of Dysmenorrhea including diet, exercise, hot application and other alternative and complimentary therapy, the women can practice it in home itself and thus the problems with Dysmenorrhea can be managed. In turn the number of absenteeism can be reduced to a great extent.

\section{OBJECTIVES OF THE STUDY:}

- To assess the level of knowledge on management of dysmenorrhea among adolescent girls during pre-test

- To assess the effectiveness of information education communication package on knowledge regardingmanagement of dysmenorrhea among adolescent girls during post-test
- To find the association between the knowledge on management of dysmenorrhea and selected demographic variables.

\section{METHODOLOGY:}

Quantitative research approach used for the study. The research design adopted for this study was quasi experimental with one group pre - test post test design. The study was conducted at Kasturba Gandhi Government Girls Higher Secondary School at Bahour, Puducherry. 60 samples were selected by using simple random sampling techniques through the lottery method.

The data were collected by structured questionnaire method for both pre - test and post - test. After the pre-test information education communication package on management of dysmenorrhea was administered to the study subjects. The data was analyzed by using both descriptive statistics (Mean, Frequency, Percentage, and Standard Deviation) and inferential statistics (chisquare test).

\section{RESULTS \& CONCLUSION:}

Distribution of level of knowledge regarding the management of Dysmenorrhea among adolescent girls during pre-test

\begin{tabular}{|c|l|c|c|}
\hline \multirow{2}{*}{ S.No } & \multicolumn{2}{|c|}{ Level of knowledge } & \multicolumn{2}{|c|}{ Pre - test } \\
\cline { 3 - 4 } & & N & \% \\
\hline 1 & Adequate knowledge (more than 75\%) & - & 0 \\
\hline 2 & Moderately adequate knowledge (50 - 75\%) & 18 & 30 \\
\hline 3 & Inadequate knowledge (less than 50\%) & 42 & 70 \\
\hline
\end{tabular}


Distribution of level of knowledge regarding the management of dysmenorrhea among adolescent girls during post-test

\begin{tabular}{|c|l|c|c|}
\hline \multirow{2}{*}{ S.No } & \multicolumn{2}{|c|}{ Level of knowledge } & \multicolumn{2}{|c|}{ Post - test } \\
\cline { 3 - 4 } & & $\mathbf{N}$ & $\%$ \\
\hline 1 & Adequate knowledge (more than 75\%) & 37 & 61 \\
\hline 2 & Moderatelyadequate knowledge (50-75\%) & 23 & 39 \\
\hline 3 & Inadequate knowledge (less than 50\%) & 0 & 0 \\
\hline
\end{tabular}

Majority of the adolescent girls those who participated in the study got adequate knowledge regarding the management of Dysmenorrhea. Out of 60 adolescent girls, 37(61\%) had adequate knowledge, 23(39\%) had moderately adequate knowledge and none of them had inadequate knowledge during post - test.

\section{Mean, standard deviation, mean difference and paird't' test value of knowledge regarding the management of dysmenorrhea among adolescent girls}

\begin{tabular}{|c|c|c|c|c|c|c|}
\hline S.No & Variables & Mean & $\begin{array}{c}\text { Standard } \\
\text { Deviation }\end{array}$ & $\begin{array}{c}\text { Mean } \\
\text { difference }\end{array}$ & $\begin{array}{c}\text { Paired 't' } \\
\text { value }\end{array}$ & P Value \\
\hline 1 & Per test & 11.10 & 4.490 & 7.54 & 38.901 & \multirow{2}{*}{$0.00 o^{* * *}$} \\
\hline 2 & Post test & 23.30 & 3.346 & & \\
\hline
\end{tabular}

The mean pre test knowledge score was 11.10 and post test knowledge score was 23.30. The standard deviation of pre test knowledge score was 4.490 and post test knowledge score was 3.346. The obtained paired 't' value was 38.901 and $\mathrm{P}$ value was 0.00o. It was highly significant at $\mathrm{P}<0.001$ level. It was inferred that the information education communication package on management ofdysmenorrhea was highly effective.

The association between the knowledge on management of dysmenorrhea and selected demographic variables revealed that there was significant association between the knowledge on management of dysmenorrhea among adolescent girls with their age, standard of studying, education status of the mother, family history of dysmenorrheal and source of information. It was significant at $\mathrm{P}<0.05$ level. There was no significant association between the knowledge on management of dysmenorrhea among adolescent girls with their age at menarche, religion, monthly family income, type of family and area of residence at $\mathrm{p}>0.05$ level.

\section{DISCUSSION:}

The main aim of the study was to assess the effectiveness of Information Education Communication package on management of dysmenorrhea among adolescent girls in Kasturibai Gandhi Government Girls Higher Secondary School at Bahour, Puducherry. Quantitative research approach used for the study. The research design adopted for this study was quasi - experimental with 
one group pre - test - posttest design. Discussions on the findings were presented based on the objectives of the study.

The mean pretest knowledge score was 11.10 and posttest knowledge score was 23.30. The standard deviation of pretest knowledge score was 4.490 and posttest knowledge score was 3.346 . The obtained paired't' value was 38.901 and $\mathrm{P}$ value was 0.000 . It was highly significant at $\mathrm{P}<0.001$ level. It was inferred that the information education communication package on management of dysmenorrhea was highly effective.

The finding were supported by Ms.Anitha.P (2007), who conducted the study to assess the effectiveness of information education communication package on dysmenorrhea and its management at selected school among 100 adolescent girls in Bangalore. The data was collected by using selfadministeredquestionnaire. The results revealed that none of them had excellent knowledge in the pretest, after giving the information education communication package posttest was done and in the majority (64\%) had excellent knowledge.

\section{RECOMMENDATIONS:}

- The study can be replicated with large sample size.

- The same study can be done with control group.

- A comparative study can be conducted among rural and urban areas as well as among teenage girls and married girls.

- Study can be conducted to assess the practices after providing education on management of dysmenorrhea.

- Health professional can be instructed to conduct the health education programme on the management of dysmenorrhea.
- A qualitative study could be carried out in depth to explore the problems associated with menstruation and ways to manage it.

\section{CONCLUSION:}

The main aim of the study was to assess the effectiveness of Information Education Communication package on management of dysmenorrhea among adolescent girls in Kasturibai Gandhi Government Girls Higher Secondary School at Bahour, Puducherry. Attaining puberty is the stepping stone from childhood to maturity. A girl becomes a woman only after attaining puberty. Dysmenorrhea is the major problem affecting the woman during each menstruation. Dysmenorrhea creates stress to the woman. Based on the results the investigator felt that there is a need for good practices like exercise, nutrition and healthy life style practices to reduce the prevalence rate. Interactive method of teaching with demonstration is an effective method of increasing the knowledge level. From this study it was clearly proved that proper Information, Education and Communication package on management of dysmenorrhea surely improves the knowledge level of the adolescent girls and there by the school absenteeism can be reduced to a great extent.

\section{REFERENCES:}

1. Arulkumaran S, Sivanesaratnam V, Kumar

P. Essentials of obstetrics. $1^{\text {st }}$ edition. New

Delhi: Jaypee Medical Publishers; 2004

2.Bader NP, Fay NT, Hammond HR. Obstetrics and gynecology. $1^{\text {st }}$ edition.Londan: WB Saunders Company Limited; 1999

3. Basavanthappa BT. Community Health Nursing $6^{\text {th }}$ edition. New Delhi: JaypeeBrothers Medical Publishers(p) Ltd; 2006 
4. DuttaDC.Text Book of gynecology. $6^{\text {th }}$ edition. Calcutta: New Central Book Agency; 2004.

5. Ganguly G, Soonawala PR. Medico - legal aspects in Obstetrics and gynecology. $1^{\text {st }}$ edition.Bangalore: JaypeeBrothers Medical Publishers(p) Ltd; 1997

6.Park K . Park's Text Book Of Preventive And Social Medicine 18 th edition. New Delhi:BanarsidasBhanotPublishers.2005 7. Anitha P. effectiveness of teaching program on dysmenorrhea and its management. Indian Journal of Midwifery. 2007 July; 14(5)
8. Mathew $\mathrm{P}$ (Dysmenorrhea and its management). Dysmenorrhea home management.2011 Jan; Available at :htt//www.pubmed.com/article/days_men orrhea_management//

9. Mechadrial TA (cause for menstrual cramps). Dysmenorrhea (home page on the internet). 2007 June; Available at: htt//www.health.com.

10. Unsal A, Ayrani U, Tozun M. Prevalence of dysmenorrhea and its effect on the quality of life. Upsala Journal of Medical Sciences. 2010 May; 115(2): 138

\section{ANALGESIA VS ANESTHESIA}

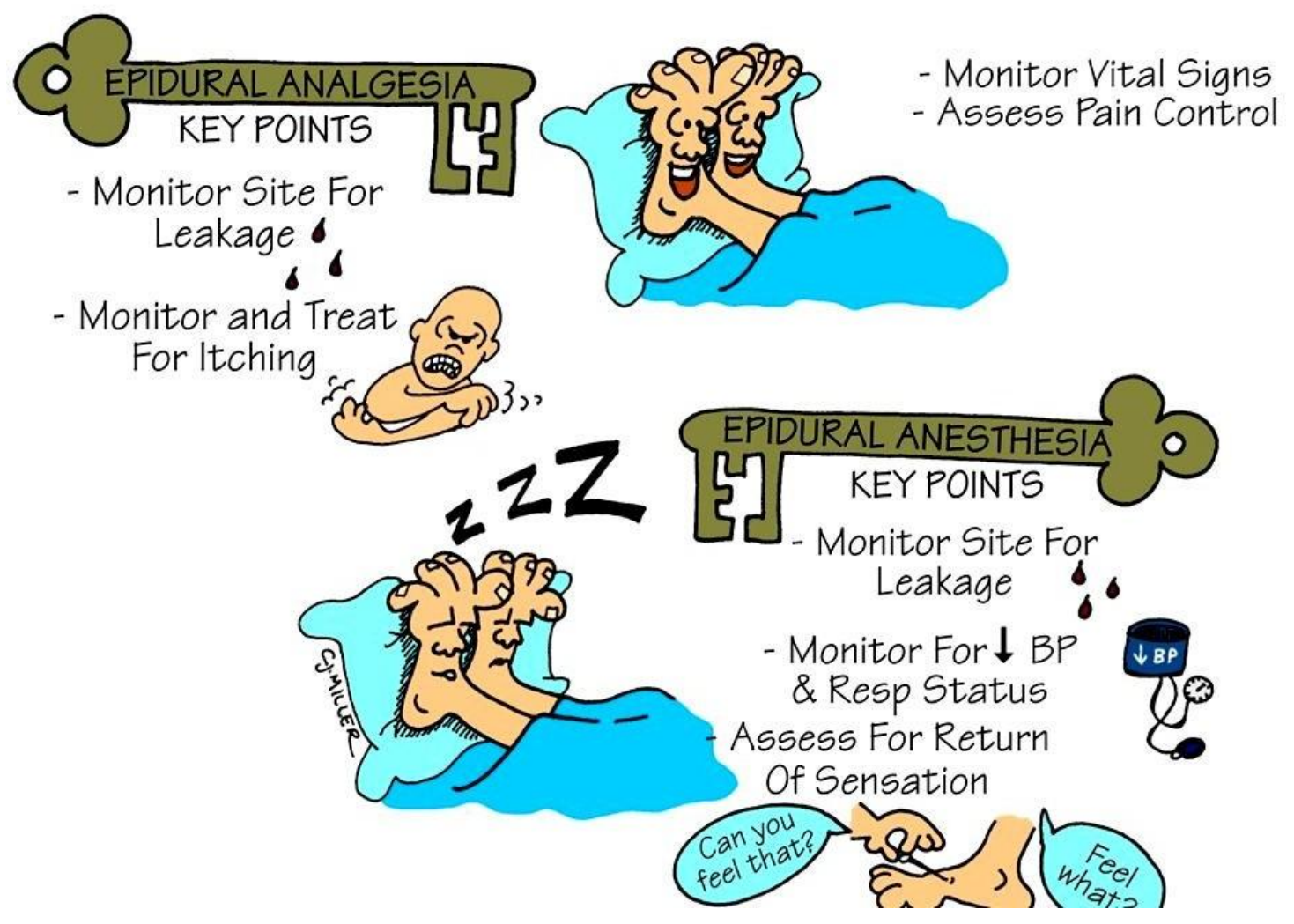

